\title{
In search for the role of thermospermine synthase gene in poplar vascular development
}

\author{
Ana Milhinhos $^{1 *}$, Andreia Matos ${ }^{1}$, Francisco Vera-Sirera $^{2}$, Miguel Blazquez ${ }^{2}$, Célia Miguel ${ }^{1}$ \\ From IUFRO Tree Biotechnology Conference 2011: From Genomes to Integration and Delivery \\ Arraial d Ajuda, Bahia, Brazil. 26 June - 2 July 2011
}

\begin{abstract}
Background
Plant polyamines are preferentially detected in actively growing tissues and have been implicated in growth and developmental processes such as embryogenesis, floral developmental, fruit ripening, senescence and stress responses [1]. Recently it has been established a link between polyamines and vascular development as it was found that, in Arabidopsis, the loss-of-function mutants of ACAULIS5 (ACL5) gene, encoding thermospermine synthase, exhibit a severe dwarf phenotype, suggesting that thermospermine acts as a regulator of stem elongation $[2,3]$. However, in trees, no studies have yet been reported. Due to the relevance of vascular development in wood formation we are investigating the role of thermospermine in vascular tissues of poplar.
\end{abstract}

\section{Materials and methods}

A search for ACL5-like sequences in Populus trichocarpa genome allowed us to identify three putative ACL5 orthologous genes. Based on the degree of sequence similarity, we have selected one of them, PtACL5, to generate transgenic plants bearing the constructs for overexpression and silencing of this gene in poplar.

\section{Results}

High expression levels of PtACL5 in overexpression transgenic lines have been found to be correlated to higher thermospermine content in leaves and young stems, but not to a higher level of other polyamines, suggesting that PtACL5 encodes a thermospermine synthase in poplar, and it is most probably an ortholog of $A C L 5$ in poplar. Interestingly, these plants display

\footnotetext{
* Correspondence: milhinho@itqb.unl.pt

${ }^{1}$ Instituto de Tecnologia Química e Biológica-Univ. Nova de Lisboa; Instituto de Biologia Experimental e Tecnológica (ITQB-UNL;BBET) Av. República, EAN, 2780-157 Oeiras, Portugal

Full list of author information is available at the end of the article
}

altered and arrested shoot development in the early stages following p35S::PtACL5 transformation, as well as severe dwarfism. Anatomical changes associated to the lack of elongation include arrested development of the root system and no elongation of the stem from the first internode onwards. Because Arabidopsisacl5 loss-offunction mutants show accelerated vessel cell death and ACL5 expression is confined to xylem vessel elements [4], we further looked for alterations in the vascular pattern of the poplar stem, and observed the development of a wider stem in dwarf plants, composed of primary vascular tissues only, lower number of metaxylem cells and with no secondary growth.

\section{Conclusions}

Overall, our results suggest that thermospermine has a regulatory role in xylem differentiation/maturation in poplar. Although a feedback control of thermospermine synthesis seems to be present in Arabidopsis, in our transgenic poplar the high levels resulting from overexpression of thermospermine synthase gene seem to overcome any turn-over that might be occurring of the excess thermospermine being produced. Currently we are pursuing the spatial localization of the ACL5 transcript in poplar plants through in situ hybridization, and by taking advantage of the generated transgenic lines we hope to understand the role of thermospermine in the vascular tissues formation in this woody species.

\footnotetext{
Acknowledgements

This work is supported by the FCT project PTDC/AGR-GPL/098369/2008 and FCT PhD grant SFRH/BD/30074/2006 (A.M.). Dr. Max Cheng for providing P. trichocarpa Nisqually-1 clone and Dr. Brian Jones for T89 hybrid clone.

\section{Author details}

${ }^{1}$ Instituto de Tecnologia Química e Biológica-Univ. Nova de Lisboa; Instituto de Biologia Experimental e Tecnológica (ITQB-UNL;IBET) Av. República, EAN, 2780-157 Oeiras, Portugal. ${ }^{2}$ Instituto de Biología Molecular y Celular de Plantas (CSIC-UPV) 46022 Valencia, Spain.
} 
Published: 13 September 2011

\section{References}

1. Kumar A, Taylor M, Altabella T, Tiburcio AF: Recent advances in polyamine research. Trends Plant Sci 1997, 2:124-130.

2. Hanzawa $Y$, Takahashi T, Michael AJ, Burtin D, Long D, Pineiro M, Coupland G, Komeda Y: ACAULIS5, an Arabidopsis gene required for stem elongation, encodes a spermine synthase. The EMBO J 2000, 19:4248-4256.

3. Knott JM, Römer P, Sumper M: Putative spermine synthases from Thalassiosira pseudonana and Arabidopsis thaliana synthesize thermospermine rather than spermine. FEBS Lett 2007, 581(16):3081-3086.

4. Muñiz L, Minguet EG, Singh SK, Pesquet E, Vera-Sirera F, Moreau-

Courtois $\mathrm{CL}$, Carbonell J, Blázquez MA, Tuominen H: ACAULIS5 controls Arabidopsis xylem specification through the prevention of premature cell death. Development 135:2573-2582.

doi:10.1186/1753-6561-5-S7-P72

Cite this article as: Milhinhos et al:: In search for the role of thermospermine synthase gene in poplar vascular development. $B M C$ Proceedings 2011 5(Suppl 7):P72.

\section{Submit your next manuscript to BioMed Central} and take full advantage of:

- Convenient online submission

- Thorough peer review

- No space constraints or color figure charges

- Immediate publication on acceptance

- Inclusion in PubMed, CAS, Scopus and Google Scholar

- Research which is freely available for redistribution

Submit your manuscript at www.biomedcentral.com/submit 